\title{
Kemiskinan dalam Novel Di Kaki Bukit Cibalak Karya Ahmad Tohari
}

\author{
Dewi Ratnaningsih ${ }^{1}$ \\ Pendidikan Bahasa dan Sastra Indonesia \\ STKIP Muhammadiyah Kotabumi
}

\begin{abstract}
Abstrak
Literature is the most optimal meda to express idea of a writer. The ideas could be on the form of feedback, critic, satire, or the reaction. The literature is the mirror of society life, so that there are some life point of views included on the novel "Di Kaki Bukit Cibalak" by Ahmad Tohari. Ahmad Tohari is very great in expressing poverty reality occurs in 1970 in this novel. The description of poverty in this novel are described on the poverty of society life. In this novel, society were prefer eating cassava than rice. They did not also have good/proper house. In the novel, the actor Mbok Rolem has only one clothes. What Ahmad Tohari described on the novel is also experienced by Indonesian on 1970 until now.
\end{abstract}

\section{Pendahuluan}

Kemiskinan adalah keadaan kurangnya kebutuhan sandang, pangan, dan papan seseorang. Sandang, pangan, dan papan mutlak diperlukan oleh manusia sebagai salah satu bentuk pertahanan hidup. Kebutuhan sandang diartikan sebagai keadaan seseorang memerlukan pakaian untuk melindungi tubuh dari kondisi udara. Selain itu, sadang diperlukan sebagai bentuk beradaban manusia yang semakin maju. Kebutuhan pangan merupakan kondisi seseorang untuk memenuhi asupan nutrisi yang berguna bagi kesehatan tubuh sedangkan kebutuhan papan diperlukan seseorang sebagai tempat berteduh dan berlindung dari hujan, panas, dan sebagainya.
Kemiskinan merupakan masalah klasik yang sampai saat ini belum terselesaikan secara tuntas. Problematika kemiskinan masih sangat kentara terjadi di negara Indonesia yang notabene negara yang memiliki sumber daya alam melimpah. Sebagai negara dengan sumber daya alam yang melimpah sangat tidak relevan jika masyarakatnya masih dalam kondisi miskin. Hal inilah yang mendorong para sastawan untuk bereaksi terhadap keadaan yang terjadi. Para sastrawan berupaya mengemukakan pendapatnya melalui karyanya. Karya menjadi sebuah media yang sesuai untuk mencurahkan kritik dan menggambarkan kondisi kemiskinan yang terjadi di Indonesia. 
Salah satu sastrawan yang kerap menggambarkan kondisi kemiskinan yang terjadi di Indonesia adalah Ahmad Tohari. Ahmad Tohari merupakan sastrawan Jawa yang lugas dan jujur dalam mengungkapkan pemikiran disetiap karyanya. Ahmad Tohari menghasilkan karyanya sekitar tahun 1970-an. Hal ini menjadikan dirinya sebagai sastrawan yang berada di titik transisi atau dapat dikatakan sebagai tokoh yang mewakili segala perubahan yang berkaitan dengan masa pertumbuhan dan perkembangan kesusastraan di Indonesia pada angkatan itu. Tokoh yang hadir dalam setiap karya sastra di tahun 1970-an dianggap sebagai wakil dari masyarakat untuk berkata, bertindak, dan meluapkan semua hal yang terjadi di dalam realitas kehidupannya.

Ahmad Tohari telah banyak menghasilkan karya. Salah satu di antaranya adalah novel Di Kaki Bukit Cibalak. Novel ini merupakan novel yang banyak menggambarkan kemiskinan di Indonesia. Novel ini ditulis pada tahun 1970. Novel Di Kaki Bukit Cibalak ini merupakan salah satu novel karya Ahmad Tohari yang pernah mendapatkan hadiah sayembara penulisan roman dari Dewan Kesenian Jakarta. Kentalnya masalah kemiskinan yang diungkap oleh Ahmad Tohari menjadi penyebab diterimanya dengan baik novel ini.
Gambaran kemiskinan yang hadir dalam novel Di Kaki Bukit Cibalak menjadi barometer kondisi kemiskinan yang terjadi di Indonesia, khususnya pada tahun 1970. Hal ini relevan dengan tahun ditulisnya novel ini. Pada tahun 1970, Ahmad Tohari sebagai sastrawan melihat dan merasakan kemiskinan di sekitarnya. Hal inilah yang mendorongnya menulis sebuah karya sastra yang kental akan nuansa kemiskinan. Karya sastra menjadi gambarkan kehidupan nyata, hal ini yang ingin dikemukakan oleh Ahmad Tohari.

Pendekatan sosiologi sastra merupakan pendekatan yang akan digunakan untuk menganalisis kondisi kemiskinan yang terdapat dalam novel $D i$ Kaki Bukit Cibalak. Beragamnya pendekatan sosiologi tidak memungkinkan untuk digunakan. Oleh karena itu, pendekatan sosiologi terhadap karya sastra menjadi teori yang akan digunakan.

\section{Sosiologi Sastra}

Sosiologi merupakan telaah yang objektif dan ilmiah tentang manusia dalam masyarakat; telaah tentang lembaga dan proses sosial (Danomo dalam Ratnaningsih, 2011:13). Lingkungan masyarakat merupakan wadah bagi manusia dalam berinteraksi sosial dengan manusia yang lainya. Dalam lingkungan masyarakat terjadi berbagai fenomena yang 
melibatkan setiap anggota masyarakat di dalamnya. Oleh karena itu, sebagai anggota masyarakat, seseorang perlu memahami berbagai fenomena yang terjadi di lingkungan masyarakat tersebut sehingga setiap anggota masyarakat dapat menjalankan peran masing-masing dengan baik.

Sosiologi sastra memunyai berbagai varian yang masing-masing dari varian tersebut memiliki kerangka teori dan metode sendiri. Dalam hal ini, Suwardi (2011:10-11) membedakan sosiologi sastra ke dalam beberapa macam pengertian.

1. Pemahaman terhadap karya sastra dengan mempertimbangkan aspekaspek kemasyarakatannya.

2. Pemahaman terhadap totalitas karya yang disertai dengan aspek-aspek kemasyarakatan yang terkandung di dalamnya.

3. Pemahaman terhadap karya sastra sekaligus hubungannya dengan masyarakat yang melatarbelakanginya.

4. Analisis terhadap karya sastra dengan mempertimbangkan seberapa jauh peranannya dalam mengubah struktur kemasyarakatan.

5. Analisis yang berkaitan dengan manfaat karya dalam membantu perkembangan masyarakat.

6. Analisis mengenai seberapa jauh kaitan langsung antara unsur-unsur karya dengan unsur-unsur masyarakat.

7. Analisis mengenai seberapa jauh keterlibatan langsung pengarang sebagai anggota masyarakat.
8. Sosiologi sastra adalah analisis institusi sastra.

9. Sosiologi sastra adalah kaitan langsung antara karya sastra dengan masyarakat.

10. Sosiologi sastra adalah hubungan searah (positivistik) antara sastra dengan masyarakat.

11. Sosiologi sastra adalah hubungan dwiarah (dialektik) antara sastra dengan masyarakat.

12. Sosiologi sastra berusaha menemukan kualitas interdependensi antara sastra dengan masyarakat.

13. Pemahaman yang berkaitan dengan aktivitas kreatif sebagai sematamata proses sosiokultural.

14. Pemahaman yang berkaitan dengan aspek-aspek penerbitan dan pemasaran karya.

15. Analisis yang berkaitan dengan sikap-sikap masyarakat pembaca.

Damono dalam Rantaningsih (2011:14) membuat klasifikasi dalam masalah sosiologi sastra menjadi tiga. Pertama, sosiologi pengarang yang me-masalahkan status sosial, ideologi sosial, dan lain-lain yang menyangkut pengarang sebagai penghasil karya sastra. Kedua, sosiologi karya sastra yang me-masalahkan karya sastra itu sendiri; yang menjadi pokok penelaahan adalah apa yang tersirat dalam karya sastra dan apa yang menjadi tujuannya. Ketiga, sosio-logi sastra yang memasalahkan pembaca dan pengaruh sosial karya sastra.

Danomo dalam Ratnaningsih (2011:14) membagi pendekatan sosiologi sastra menjadi tiga bagian yakni: 1) konteks 
sosial pengarang, hal ini ada hubungannya dengan posisi sastrawan dalam masyarakat dan kaitannya dengan masyarakat pembaca, 2) sastra sebagai cermin masyarakat, hal ini berhubungan dengan kaitan posisi kedudukan sastra sampai sejauh mana dapat dianggap mencerminkan keadaan masyarakat, 3) fungsi sosial sastra, dalam hal ini berhubungan dengan sejauh mana nilai sastra dikaitkan dengan nilai sosial? dan sejauh mana nilai sastra dipengaruhi nilai sosial?

\section{Sastra sebagai Cermin Masyarakat}

Sastra sebagai cermin masyarakat adalah bahwa posisi karya sastra akan memengaruhi segala sikap dan sifat masyarakat dalam menjalani kehidupan. Laurenson dan Swingewood dalam Endraswara (2011:87) memaparkan bahwa ada beberapa strategi yang patut ditempuh dalam menarik kejelasan hubungan sosiologi dan sastra, yaitu dengan cara pendekatan karya sastra melalui struktur dalam seperti irama, metafora, pelukisan watak, dinamika plot yang dihubungkan dengan masyarakat. Oleh karena itu, sosialogi sastra secara murni adalah penelitian mengenai hal-hal tentang: a) studi ilmiah manusia dan masyarakat secara objektif, b) studi lembaga sosial melalui sastra dan sebaliknya, c) studi proses sosial. Semua bentuk studi di atas merupakan penghayatan teks sastra terhadap stuktur sosial. Sastra sebagai cermin masyarakat dikatakan sebagai sesuatu yang merefleksi kehidupan nayata. Hal ini relavan dengan pendapat Endraswara (2011: 169) yang mengatakan bahwa cermin itu benda yang tembus pandang. Cermin dapat memantulakan cahaya. Sastra itu juga sebuah cermin. Membaca sastra, sama halnya sedang bercermin diri sejak awal, kehadiran kritikus sastra, krtikus sosiologi sastra telah memperhatikan sastra dan cermin. Sastra yang indah, karena mampu mencerminkan dunia sosial secara estetis.

\section{Kemiskinan dalam Novel Di Kaki Bukit Cibalak}

"Ke Balai Desa? Keterangan apa, Nak?"

"Keterangan yang menyatakan bahwa kau benar-benar miskin sehingga tidak mampu membayar biaya pengobatan.

Kutipan di atas merupakan kutipan yang memaparkan tentang adanya gambarkan kemiskinan warga Desa Tanggir. Ketidakmampuan untuk membiayai pengobatan merupakan salah satu indikasi bahwa tokoh yang ada dalam cerita merupakan tokoh yang miskin. Ia harus pergi ke balai desa untuk meminta surat keterangan mskin sebagai bukti bahwa ia benar-benar miskin dan tidak mampu unutk membayar biaya pengobatan. Kutipan lain yang menunjjukkan adanya 
kemiskinan dalam novel terdpat di bawah ini.

Perempuan lugu yang amat miskin itu terharu. Ternyata ada seseorang yang mau menganggapnya sama dengan orang-orang lain, dan mau menolong.

Pernyataan 'perempuan lugu yang amat miskin itu terharu' merupakan pernyataan langsung yang diberikan oleh pengarang sebagai bukti bahwa tokoh yang ada di dalam novel merupakan tokoh yang miskin. Pengarang mengungkapkan secara langsung kondisi tokoh yang miskin sebagai bentuk luapan kerisuan hatinya dengan kondisi yang terjadi di sekitarnya. Dengan pengungkapan secara langsung, pengarang berharap, pembaca dapat langsung memerima apa yang ingin dikemukan oleh pengarang. Kutipan langsung lainnya tentang kemiskinan dalam novel juga terdapat dalam kutipan di bawah.

Rupanya kedua orang dokter itu merasa sulit untuk menerima bayaran dari seorang janda miskin dari Desa Tanggir.

Seperti halnya kutipan sebelumnya, kutipan ini juga merupakan kutipan langsung dari pengarang. Kata 'janda miskin' merupakan kata yang langsung merujuk pada seorang wanita tanpa suami yang dalam kondisi kekurangan. Kata tersebut digunakan pengarang sebagai ungkapan langsung bahwa tokoh adalah seseorang yang miskin atau kekurangan.
Pengungkapan secra langsung terkadang menjadi solusi bagi pengarang dalam mengungkapkan kondisi hatinya yang gerah terhadap kondisi kemiskinan yang terjadi. Kutipan kemiskinan selanjutnya adalah.

Tidak ada bilik-bilik dalam rumah Mbok Ralem. Di sudut bagian timur ada tungku dan tempayan. Beberapa perkakas dapur, cerek, kuali, dan gayung di atas tungku itu. Pambudi yakin, tungku itu jarang dinyalakan, karena hanya terdapat sedikit abu di dalamnya. Barangkali tadi pagi Mbok Ralem sekeluarga sarapan singkong bakar. Kulitnya berserakan di bawah satu-satunya tempat tidur tanpa tikar di dalam rumah itu.

Kutipan di atas menggambarkan kondisi kemiskinan tokoh Mbok Ralem. Kondisi kemiskinan yang diungkapkan berupa jarangnya tokoh menggunakan alat memasaknya (tidak bisa memasak karena tidak ada yang dimasak). Selain itu, seringnya tokoh memakan singkong bakar merupakan hal yang mengindikasi adanya kemiskinan. Tidak mampunya tokoh untuk membeli beras memaksanya untuk memakan singkong yang hanya dibakar. Kutipan selanjutnya terkait kemiskinan terdapat dalam kutipan di bawah ini.

Kedua anak Mbok Ralem duduk diam, hanya pelupuk matanya saja yang bergerak-gerak. Perutnya buncit. Sedikit makanan yang masuk ke perutnya. 
Sedikit makanan yang masuk, perut buncit, terdiam layu merupakan hal-hal yang mengindikasi adanya kekurangan pangan tokoh yang ada di dalam novel. Kondisi tersebut merupakan kondisi kemiskinan yang dialami kedua anak Mbok Ralem. Kutipan kemiskinan lainya juga terdaat di bawah ini.

Pak Mantri mengatakan bahwa diperlukan waktu beberapa hari untuk mengembalikan kekuatan tubuh Mbok Ralem sebelum operasi bisa dilaksanakan. Perempuan itu menderita kekurangan gizi yang parah.

Kutipan di atas dikatakan sebagai kutipan yang menggambarkan kemiskinan. Gambaran kemiskinan terlihat dari pernyataan dari pak mantri bahwa Mbok Ralem menderita kekurangan gizi yang parah. Jarangnya Mbok Ralem mengonsumsi nasi menjadi menyebab kurangnya asupan gizi untuk tubuh lemahnya. Nasi yang seharusnya menjadi makanan pokok tidak ammpu dibeli sehingga ia harus mengganti nasi dengan jagung yang dibakar. Kutipan kemiskinan lainnya terdapat di bawah ini.

Di depan sebuah toko yang tutup ia melihat seorang pedagang pakaian bekas. Pambudi ingat, Mbok Ralem tidak membawa pakaian ganti barang sepotong pun. Bukan lupa, tetapi Mbok Ralem tidak mempunyai pakaian yang lain. Maka Pambudi membeli dua helai kain batik bekas dan sepotong kebaya yang masih baik.

Gambaran kemiskinan di atas tergolong dalam ketidakcukupan dalam kebutuhan sandang. Mbok Ralem hanya memiliki pakaian yang digunakannya. Mbok Ralem tidak pernah berpikir untuk memunyai pakaian yang layak. Hal ini karena Mbok Ralem tidak memiliki uang untuk membelinya. Kebutuhan pangan saja tidak mampu dipenuhinya apalagi kebutuhan sandang.

\section{Kemiskinan di Indonesia pada Tahun 1970}

Badan Pusat Statistik menginformsikan tingkat kemiskinan pada tahun 1970 mencapai 60,1\%. Hal ini sama halnya berarti sekitar 70 juta penduduk Indonesia dikatakan sebagai masyarakat miskin. Pada masa kepemimpinan Soeharto, terjadi menurunan inflasi dan pengurangan tingkat kemiskinan sampai 40,1\%. Hal tersebut terjadi pada tahun 1976. Keberhasilan penurunan laju inflasi dan pengurangan kemiskinan yang terjadi tidak diimbangi dengan keberhasilan pemerataan ekonomi (Wicaksana, 2007:16).

Wacana tentang kemiskinan terus menjadi bahasan aktual yang selalu dibicarakan. Kemiskinan merupakan suatu masalah rumit yang hampir dialami oleh setiap negara berkembang, tak terkecuali 
Indonesia. Kemiskinan adalah sebagai suatu kondisi atau keadaan ketidakcukupan sandang, pangan, dan papan yang dialami oleh seseorang atau sekelompok orang. Akibat dari ketidakcukupan sandang, pangan, dan papan tersebut membuat seseorang atau sekelompok orang itu tidak dapat hidup secara layak. Kekurangmampuan tersebut terjadi pada tingkat pemenuhan kebutuhan-kebutuhan yang mendasar seperti: makan-minum, berpakaian, bertempat tinggal atau rumah, dan kesehatan (Astika, 2010:21).

Contoh gambaran kemiskinan di Indonesia tahun 1970 terjadi di daerah Wonogiri, Jawa Tengah. Mahalnya harga beras membuat sebagian warga miskin di Wonogiri, Jawa Tengah beralih makan nasi tiwul sebagai makanan pokok pengganti beras. Pilihan ini ditempuh karena mereka tidak mampu menjangkau harga beras yang mahal. Di Kabupaten Wonogiri, nasi tiwul pernah menjadi makanan pokok warga pada era tahun 1970-an, terutama bagi warga yang tinggal di Wonogiri Selatan seperti Kecamatan Praci, Giri Tontro dan Parang Gupito. Saat harga beras mahal mereka kembali beralih makan tiwul karena sebagian besar warga masih miskin. (www.Indosiar.co.id).

Gambaran kemiskinan selanjutnya terlihat di daerah Bojolajar. Daerah berpenduduk miskin dengan makanan pokok gaplek dan singkong sangat jauh dari kesejahteraan. Seorang tabib bernama dr.Gunawan berupaya mengangkat derajat dan harga diri rakyat pemakan gaplek dan singkong di sana walaupun dengan fasilitas sederhana (Tempo, 14 Agustus 1971).

\section{Simpulan}

Sastra sebagai cermin masyarakat merupakan ungkapan yang relevan jika dilakukan perbandingan antara masalah kemiskinan yang ada di novel Di Kaki Bukit Cibalak dengan realitas keadaan di Indonesia. Ahmad Tohari sebagai pengarang berupaya untuk menunjukkan eksistensinya sebagai pengarang yang peka terhadap kondisi kemiskinan yang ada di negaranya. Melalui karya sastra ia memaparkan kondisi kemiskinan yang terjadi di sekitarnya. Ahmad Tohari mengungkapkan bentuk-bentuk kemiskinan secara kongkret dan menyajikannya dalam bentuk karya sastra. Secara umum kondisi kemiskinan yang digambarkan Ahmad Tohari sangat relevan dengan kondisi kemiskinan yang terjadi di Indonesia.

Gambaran kemiskinan dalam novel Di Kaki Bukit Cibalak yang ditampilkan oleh Ahmad Tohari berupa keadaan kekurangan pangan dan papan. Kekurangan pangan dalam novel, seperti seringnya memakan singkong daripada beras, juga sangat relevan dengan realitas masyarakat 
Indonesia di daerah Wonogiri dan

Bojolajar. Kurangnya kebutuhan papan dalam novel sangat relevan dengan realitas masyarakat Indonesia yang masih belum memiliki rumah yang layak. Kekurangan sandang pun dirasakan oleh masyarakat Indonesia. Hal tersebut jelas terjadi karena setiap orang akan mementingkan kebutuhan pangan terlebih dahulu daripada kebutuhan sandang.

\section{Daftar Rujukan}

Astika, Ketut Sudhana. 2010. Budaya Kemiskinan di Masyarakat: Tinjauan Kondisi Kemiskinan dan Kesadaran Budaya Miskin di Masyarakat. Skripsi Tidak Ditebitkan. Bali: Universitas Udayana.

Endraswara, Suwardi. 2010. Metodologi Penelitian Sastra. Yogyakarta: Pustaka widyatama.
Ratnaningsih, Dewi. 2011. Tinjauan Sosiologi Novel Di Kaki Bukit Cibalak Karya Ahmad Tohari dan Pembelajarannya di SMA. Skripsi Tidak Diterbitkan. Kotabumi: STKIP Muhammadiyah Kotabumi.

Suwardi.2011. Sosiologi Sastra. Universitas Negeri Yogyakarta: Yogyakarta.

Tempo. 1971, 14 Agustus. Menahan Lapar di Bojolajar. Hlm. 2. (Daring), Tersedia:http://majalah.tempointera ktif.com/id/arsip/1971/08/14/DS/m bm.19710814.DS57787.id.html. (21 Agustus 2017)

Wicaksana, Sunarwan Arif. 2007. Analisis Kesenjangan Kemiskinan Antar Provinsi di Indonesia Periode Tahun 2000-2004. Skripsi Tidak Diterbitkan. Yogyakarta: Universitas Islam Indonesia.

www.Indosiar.co.id. http://www.indosiar.com/fokus/7513 9/warga-miskin-makan-nasi-tiwul. 